\title{
Psychological Model of Development of Professional Axiological Orientations in Prospective Teachers at the Stage of Higher Education
}

\author{
Olga Vasilyevna Kudashkina ${ }^{1}$, Tatyana Victorovna Savinova ${ }^{1}$, Natalia Alexandrovna Vdovina ${ }^{1}$ \\ ${ }^{1}$ Mordovian State Pedagogical Institute, Studencheskaya str., 11a, Saransk, 430007, Russia \\ *Corresponding author E-mail: kudashkina.o.v@mail.ru
}

\begin{abstract}
The article defines the relevance of developing professional axiological orientations in prospective teachers and reviews the main research ideas on the topic. The aim of the article was to create a psychological model of development of professional axiological orientations of prospective teachers at the stage of higher education. The main methods of the study included theoretical analysis of the research literature on the topic of teachers' axiological orientations, as well as the method modelling that included the creation of the model of development of professional axiological orientations of prospective teachers at the stage of higher education. The authors presented the model that included the following inter-connected blocks: developmental, processing and resulting blocks. The developmental block includes the content, psychological-pedagogic conditions and mechanisms of the prospective teachers' professional axiological orientations development. The processing block defines the stages of the development. The resulting block includes the criteria and levels of the development. The content of the article reveals an opportunity for setting new goals in conducting professional axiological development of prospective teachers. Reaching these goals by integrating the international and national experience would help to efficiently organize the educational and mentoring process at the stage of higher education, which defines the future perspective of the study.
\end{abstract}

Keywords: Development; Higher education process; Model; Professional axiological orientations; Teacher.

\section{Introduction}

The society currently experiences noticeable social-economic and spiritual transformations that define the changes in the whole educational system, including professional education. Modernization of Russian education raised multiple issues related to the need of preparing a new generation of competent teachers that are capable of overcoming the emerging difficulties, working creatively, being ready to perfect themselves and self-actualize in the professional activity.

Therefore, due to these considerations, higher education becomes especially relevant, because, during this stage, prospective teachers develop the main ideas about the content and specifics of the chosen profession; they develop primary professional skills and abilities and search for the ways of professional selfperfection.

One of the priority directions of prospective teachers' training is the improvement of their professional competence based on the development of axiological orientations. Their development is especially relevant because teachers' axiological orientations manifest in the educational results of students' activity.

In the present article, we aimed at creating a model of development of professional axiological orientations of prospective teachers at the stage of higher education.

The goals of the research study were:

1. To analyze psychological and pedagogical literature on the topic of the study.
2. To create a psychological model of development of professional axiological orientations of prospective teachers at the stage of higher education.

3. To define the content, psychological-pedagogic conditions and mechanisms of development of the prospective teachers' professional axiological orientations development.

4. To reveal the main stages of the development.

To define the criteria and levels of the development.

\section{Methods}

In order to reach the goals of the study, we used the following methods: theoretical analysis of the research literature on the topic, as well as the method modelling that included the creation of the model of development of professional axiological orientations of prospective teachers at the stage of higher education.

\section{Results}

Theoretical analysis of psychological and pedagogic literature allowed establishing that the current research operates such concepts, as "values", "axiological orientations", "professional axiological orientations", "pedagogic values". These categories are addressed in the works of international $[1,2,3]$, and others) and Russian researchers $[4,5,6]$ and others).

Recently, a lot of international studies have been published on the topic of the individual's values and axiological orientations. They 
include studies of individual personality values and the paradigm of motivational goal of axiological orientations and universal basic human values $[1,7]$; studies related to revealing the connection between individual personality values and professional values [8]; the relation between values and individual's anxiety [9]; the relation between value and aggressiveness [10]; the relation between values and subjective well-being [11]; the relation between values and behavior $[12,13]$; the relation between values and personality traits [14]; study of correspondence between axiological orientations and self-regulation [15]; study of axiological orientations in children [16]; study of axiological orientations and analysis of their changes during the entire lifespan [17], and others.

Russian psychological and pedagogical literature presents theoretical predispositions for solving the problem of increasing the efficiency of the professional-axiological orientations development in prospective teachers. The scientific works focus on the problem of developing students' and teachers' axiological orientations, and the technologies of developing professionally relevant axiological orientations in prospective teachers. Some of the current studies addressed separate aspects of this problem, such as development of values as a condition for perfecting a teacher's professional competence [18], development of axiological orientations in prospective teachers by means of personal and professional self-actualization in a pedagogical institute [19], development of axiological orientations in prospective physical education of teachers in the field of life safety $[20,21]$, development of axiological orientations in primary-school teachers [22], organization of educational and mentoring activity in college according to the aim on establishing professional-pedagogical system of values in prospective teachers [23], moral and spiritual mentoring of a teachers' personality [24], and others.

At the Department of Psychology and Therapeutic Pedagogics of M.E. Evsevyev Mordovia State Pedagogic Institute, the research laboratory "Development of professional competence of teachers and psychologists in the system of life-long education" studies the issues of establishment and development of individual's axiological orientations at different age and professional stages of his/her development: school and university students, teachers, tutors and psychologists $[25,26,27]$ and others).

It is crucial for our study to use the definition of the concept of "professional axiological orientations of a teacher" that was proposed by Yu.V. Vardanyan and N.A. Vdovina, who define it as a system of relevant robust affirmations, beliefs and preferences that become the foundation for the selective attitude towards the subjects of the educational process and the professional activity [6].

Analysis of the studies of the russian psychologists allowed defining the concept of "professional axiological orientations of prospective teachers" as a system of crucial and the most robust professional affirmations and principles that are established and consolidated during higher education in the process of educational activity and that significantly affect the development of graduates' personality.

We created a psychological model of development of professional axiological orientations of prospective teachers at the stage of higher education that included the following blocks: developmental, processing and resulting.

The developmental block of the model includes the content, psychological-pedagogic conditions and mechanisms of development of professional axiological orientations of prospective teachers.

The content includes educational subjects of the psychological block that facilitate the development (such as the course in Psychology, Pedagogical psychology and Psychology of professional-axiological development of a teacher).

The abovementioned subjects help developing students':

Knowledge:

- In the field of teachers' psychological competence;
- About the stages, levels and criteria of teachers' proficiency;

- About the mechanisms and psychological techniques of establishing the system of teachers' axiological orientations;

- About the mechanisms of self-development and self-perfection;

- About the establishment and development of positive professional axiological orientations in prospective teachers;

- Abilities:

- To perform diagnostics, correction and development of teachers' professional axiological orientations;

- To use the modern psychological techniques of teachers' professional development;

- To develop and conduct self-education programs;

- Skills:

- To master the basis of studying the axiological content of professionally-relevant orientations of a teacher;

- To master the ways of their self-development and selfeducation;

- To master the psychological techniques of teachers' selfdevelopment.

An important source of development of professional axiological orientations of prospective teachers at the stage of higher education is the educational and industrial internship that combines the opportunities to present oneself in the pedagogical activity and to define the ways of professional self-perfection and development of psychological competence. Educational and industrial internship in the educational institutions has a large potential for self-observation of the personal and professional changes that occurred during the internship with the aim of selfdevelopment and self-education.

At the stage of higher education, it is necessary to create a system of psychological and pedagogical conditions in order to develop professional axiological orientation. They include:

-Content of education (it implies introducing the subjects that strongly help in establishing and developing professional axiological orientations in prospective teachers in the "Pedagogical education" study program);

-Axiological-oriented educational environment of a college (it defines the ability to directly and effectively influence the development of students' axiological professional orientations based on the general humanitarian and pedagogical values);

-Psychological support of a personality at the stage of higher education (psychological diagnostics, psychological and pedagogical development, psychological and pedagogical education, psychological counseling);

-Engagement of prospective teachers in self-education and selfdevelopment activity that serves as a catalyst in the process of interiorizing professional axiological orientations.

The majority of researchers highlight the following main mechanisms of developing axiological orientations: interiorization, exteriorization, identification and reflection (B.G. Ananyev, L.S. Vygotsky, A.N. Leontyev, V.A. Petrovsky, B.F. Lomov, and others) that help the students to acquire and claim the professional values of a teacher.

The processing block defines the main stages of development of professional axiological orientations.

The stages of development:

1) Actualization and expansion of students' theoretical knowledge about professionally relevant axiological orientations of a teacher;

2) Comprehension of axiological orientations of a teacher;

3) Internal acceptance of professionally relevant axiological orientations;

4) Actualization of professional axiological orientations in the practical work and their consolidation in the personality orientation of prospective teachers.

The resulting block includes the criteria and levels of development of professional axiological orientations of prospective teachers.

We will further describe the levels of development:

High level of development is defined by: 
- The presence of a wide range of ideas about teachers' professional axiological orientations;

- The comprehension and awareness of teachers' professional axiological orientations;

- The internal acceptance of teachers' professional axiological orientations;

- The positive attitude towards the upcoming work and the established system of educational and professional motives;

- The strong need for self-development, self-education and selfactualization according to higher values.

- Average level of development is defined by:

- The presence of vague ideas about teachers' professional axiological orientations;

- Incomplete comprehension and awareness of teachers' professional axiological orientations;

- Partial internal acceptance of teachers' professional axiological orientations;

- The positive attitude towards the upcoming work in the educational system and partial awareness of the educational and professional motives;

- Insufficiently manifested urge for self-development and selfperfection.

- Low level of development is defined by:

- Superficial ideas about teachers' professional axiological orientations;

- Lack or weak manifestation of comprehension and awareness of teachers' professional axiological orientations;

- Lack of readiness to accept teachers' professional axiological orientations;

- The manifestation of negative attitude towards the upcoming work in the educational system and absence of the educational and professional motivation;

- The absence of urge for self-development and self-perfection.

- Criteria for development of professional axiological orientations:

- Development of axiological attitude towards teachers professional activity;

- Comprehension of the content and meaning of professional axiological orientations;

- Readiness to actualize the professional axiological orientations;

- Development of motivation for the pedagogic profession;

- Development of a positive attitude towards the upcoming professional activity in the educational system.

\section{Discussion}

The content of the present article reveals an opportunity for setting new goals in conducting professional axiological development of prospective teachers. Reaching these goals by integrating the international and national experience would help efficiently organizing the educational and mentoring process at the stage of higher education, which defines the future perspective of the study.

\section{Conclusion}

We can make the following conclusions based on the theoretical study:

1. In the current situation of the educational system reforms and rethinking of the goals for building a professional career, the problem of developing teachers' professional axiological orientations at the stage of higher education becomes especially relevant.

2. We define professional axiological orientations of prospective teachers as a system of the main and the most constant professional affirmations and principles that are established and consolidated during higher education in the process of educational activity and that significantly affect the development of graduates' personality.

3. The article proposes a psychological model that includes interconnected blocks: developmental, processing and resulting blocks.

4. Implementing the psychological model would facilitate the development of professional axiological orientations in prospective teachers at the stage of higher education.

\section{Acknowledgement}

The study was supported by a grant for conducting research in the priority fields of scientific activity of the partner universities with the network interaction (South Ural State Humanitarian-Pedagogic University and M.E. Evsevyev Mordovia State Pedagogic Institute) on the topic of "Modern technologies of development of professional axiological orientations in prospective teachers at the stage of higher education".

\section{References}

[1] Schwartz SH (1992), Universals in the content and structure of values: Theoretical advances and empirical tests in 20 countries. Advances in experimental social psychology 25, 1-65.

[2] Consiglio C, Cenciotti R, Borgogni L, Alessandri G \& Schwartz SH (2016), A New Measure of Work Values. Journal of Career Assessment 25, 405-422.

[3] Cieciuch J, Schwartz SH \& Davidov E (2015), Values, Social Psychology of. In: James D. Wright (editor-in-chief). International Encyclopedia of the Social \& Behavioral Sciences (issue Second Edition), Oxford: Elsevier, 41-46.

[4] Baeva LV, Tsennostnye osnovaniya tsennostnogo bytiya: opyt ekzistantsialnoy aksiologii [Axiological bases of axiological being: an experience of existential axiology]. Moscow: Prometey; MPGU, 2003.

[5] Bubnova SS (2015), Sistemoobrazuyuschie faktory individualnosti - tsennostnye orientatsii lichnosti $i$ PVK subyekta deyatelnosti [System-integrating factors of individuality - axiological orientations of a personality and PRQ of a subject of activity]. Cheboksary: Izdatelsko-poligraficheskaya kompaniya "Novoe vremya".

[6] Leontyev DA (2007), Psikhologiya smysla: priroda, stroenie dinamika smysloviy realnosti [Psychology of meaning: nature, structure and dynamics of the reality of meaning]. Moskva: Smysl.

[7] Schwartz SH (2015), Basic individual values: Sources and consequences. In D. Sander and T. Brosch (Eds.) Handbook of value. Oxford: Oxford University Press, 63-84.

[8] Ros M, Schwartz SH \& Surkiss S (1999), Basic individual values, work values, and the meaning of work. Applied psychology 48(1), 49-71.

[9] Schwartz SH, Sagiv L, Boehnke K (2000), Worries and Values. Journal of Personality 68(2), 309-346.

[10] Benish-Weisman M (2015), The interplay between values and aggression: longitudinal study. Developmental Psychology 51, 6776.

[11] Schwartz SH \& Sagiv L (2000), Value priorities and subjective well-being: Direct relations and congruity effects. European Journal of Social Psychology 30, 177-198.

[12] Bardi A \& Schwartz SH (2003), Values and Behavior: Strength and Structure of Relations. Personality and Social Psychology Bulletin 29(10), 1207-1220.

[13] Daniel E, Bilgin AS, Brezina I, Strohmeier CE \& Vainre M (2015), Values and helping behavior: A study in four cultures. International Journal of Psychology 50(3), 186-192.

[14] Roccas S, Sagiv L, Knafo A \& Schwartz SH (2009), The big five personality factors and personal values. Personality and social psychology bulletin 28 (6), 789-801.

[15] Woltin KA \& Bardi A (2017), Fitting motivational content and process: A systematic investigation of fit between value-framing and self-regulation. Journal of Personality. DOI: 10.1111/jopy.12369/full

[16] Collins P, Lee J, Sneddon J \& Doering A (2017), Examining the consistency and coherence of values in young children using a new 
animated values instrument. Personality and Individual Differences 104, 279-285.

[17] Gouveia VV, Vione KC, Milfont T \& Fischer R (2015), Patterns of Value Change During the Life Span: Some Evidence from a Functional Approach to Values. Personality and Social Psychology Bulletin 41(9), 1276-1290.

[18] Barbashova LI (2014), Razvitie professionalno-tsennostnykh orientatsii $\mathrm{V}$ pedagogicheskoy deyatelnosti uchetelya. [Development of professional axiological orientations in teachers' professional activity]. Vestnik Chelyabinskogo gosudarstvennogo pedagogicheskogo universiteta 10, 176-181.

[19] Panina SV, Gotovtseva NV, Zalutskaya SYu (2016), Formirovanie tsennostnykh orientatsii buduschikh pedagogov posredstvom lichnostno-professionalnoy samoaktualizatsii v vuze [Development of axiological orientations in prospective teachers by means of personal and professional self-actualization in college]. European social science journal 5, 227-233.

[20] Akamov VV \& Shukshina TI (2014), Diagnostika sformirovannosti urovnya razvitiya tsennostnykh osnov professionalnogo samosoznaniya studentov fakulteta fizicheskoy kultury. [Diagnostics of development level of axiological bases of professional self-awareness in students of the department of physical education]. Teoriya i praktika fizicheskoy kultury $i$ sporta $8,22-25$.

[21] Karpova EA, Akamov VV \& Shukshina TI (2017), Professionalnotsennostnye orientatsii $\mathrm{u}$ buduschikh uchiteley fizicheskoy kultury $\mathrm{v}$ oblasti bezopasnosti zhiznedeyatelnosti [Professional axiologica orientations in prospective physical education teachers in the field of life safety]. Problemy sovremennogo pedagogicheskogo obrazovaniya $11,15-17$.

[22] Perekrestiva TS (2017), Formirovanie tsennostnykh orientatsii u uchiteley nachalnykh klassov. [Development of axiologica orientations in primary-school teachers]. Grani poznaniya 3, 29-33.

[23] Androsova YuV \& Vershinina LV (2015), Tsennostnye orientatsii i motivatsiya vybora professii uchitelya kak komponenty professionalno-pedagogicheskogo mirovozzreniya studentov vuza. [Axiological orientations and motivation for choosing the teacher's work as the components of professional pedagogical worldview of college students]. Vestnik Chelyabinskogo gosudarstvennogo pedagogicheskogo universiteta 9, 9-14.

[24] Martynova EA \& Enaleeva NI (2016), Dukhovno-nravstvennoe vospitanie lichnosti pedagoga $v$ obrazovatelnom prostranstve vuza [Spiritual and moral mentoring of a teacher's personlity in the educational space of a college]. Gumanitarnye nauki i obrazovanie 4, 26-30.

[25] Vdovina NA \& Sergunina SV (2014), Razvitie sotsialnogo myshleniya i professionalno-tsennostnykh orientatsii bakalavrov napravleniya podgotovki "pedagogicheskoe obrazovanie" v protsesse izucheniya kursov po vyboru [Development of social intelligence and professional axiological orientations in bachelor students of Pedagogical education specialty during the elective courses]. Gumanitarnye nauki i obrazovanie 1, 20-24.

[26] Kudashkina OV (2011), Osobennosti razvitiya tsennostnykh orientatsiy pedagoga doshkolnogo obrazovaniya na etape vuzovskogo obucheniya [Specifics of developing axiological orientations in pre-school teachers at the stage of higher education]. Gumanitarnye nauki i obrazovanie 4, 79-81.

[27] Savinova TV \& Biryuleva EI (2016), Proektirovanie programmy razvitiya tsennostnykh orientatsii buschikh psikhologov $\mathrm{v}$ obrazovatelnom prostranstve pedagogicheskogo vuza [Creating a program for developing axiological orientations in prospective psychologists in the educational space of a pedagogical university]. Izvestiya Volgogradskogo gosudarstvennogo pedagogicheskogo universiteta 5(109), 38-42. 